RESEARCH ARTICLE

\title{
Preschool and early primary school age children learning of computational thinking through the use of asynchronous learning environments in the age of Covid-19
}

\author{
Evaggelia Skaraki $^{1^{*}}$ Fotios Kolokotronis $^{2}$ \\ ${ }^{1}$ Department of Preschool Education, University of Crete, Crete, Greece \\ ${ }^{2}$ Department of Primary Education, University of Crete, Crete, Greece
}

\section{Check for updates}

${ }^{*}$ Correspondence to: Evaggelia Skaraki, Department of Preschool Education, University of Crete, Crete, Greece; Email: evask@ hotmail.gr

Received: December 8, 2021;

Accepted: December 28, 2021

Published: January 1, 2022.

Citation: Skaraki, E., \& Kolokotronis, F. (2022) Preschool and early primary school age children learning of computational thinking through the use of asynchronous learning environments in the age of Covid-19. Adv Mobile Learn Educ Res, 2(1): 180-186. https://doi.org/10.25082/AMLER.2022.01.002

Copyright: () 2022 Skaraki \& Kolokotronis. This is an open access article distributed under the terms of the Creative Commons Attribution License, which permits Creative Commons Attribution License, which permits
unrestricted use, distribution, and reproduction in any medium, provided the original author and source are credited.

\begin{abstract}
This current study aims to examine through a literature review whether children of preschool and early primary school age can be taught distance computational thinking (CT) through asynchronous learning environments in the age of covid. Over the past few years in Greece, a sharp rise in computational thinking has been noted as both students and teachers feel the need to create more imaginative and interactive ways. The study results illustrate the significance of digital media in the educational process and the educator's crucial role in using such digital tools in preschool and early primary school age. The cooperation between educators of preschool age and teachers of Information Technology could offer new dimensions and provide numerous benefits to the learning process. Distance learning programs could help teachers' training process through properly structured material that corresponds more effectively to the learning of $\mathrm{CT}$.
\end{abstract}

Keywords: computational thinking, Covid-19, primary education, distance education

\section{Introduction}

Digital media have significantly penetrated people's lives in Western societies, while the development of Computational Thinking (CT) has been introduced in the educational policies of many developed countries (Papadakis \& Kalogiannakis, 2017). In a similar vein, new educational technologies have been developed to introduce preschool and early primary school children more actively to CT activities (Vaiopoulou et al., 2021). As Wing (2006) defines: “... computational thinking is not only reserved for those who are related to the field of Computer Science but rather a general competence reserved for all. In addition to reading, writing, and math, we must add computational thinking to every child's analytical ability". In 2011, she also added to her definition "computational thinking constitutes the operations of thought which involve forming and solving problems in such a way that they are represented in a form that an information processing agent can effectively implement." In developed countries, CT has already been introduced to children of preschool age as it is considered a necessary skill for current pupils in contemporary society. The integration of technology in education is an orientation of scientific literacy, while within the framework of scientific literacy, great emphasis is placed on learning based on an investigation (Skaraki, 2021; Kalogiannakis et al., 2018). In our days, young children live with technology and use it in their daily lives (Fessakis et al., 2015). The existence of cost-effective and mobile smart devices allows children aged under eight coming from low-income family backgrounds to access smart mobile devices (smart mobile phones tablets) (Guernsey \& Levine, 2016). Likewise, research has shown that children develop skills and competencies that exceed their expected perceptual and kinetic skills development through touch screens and their participation in educational activities. Teaching through mobile devices and applications improves students' learning results in preschool age (Ampartzaki et al., 2021; Kalogiannakis et al., 2018; Papadakis \& Kalogiannakis, 2019).

Nevertheless, COVID-19 does not only cause health crises all over the world, but it also affects all aspects of life, including the educational field (Alea et al., 2020). The sudden transition to distance teaching forced both teachers and students to adjust their educational practices by using digital platforms and educational approaches that were unknown (Pinto et al., 2020). According to Anastasiadis (2004), distance teaching constitutes an institutionalized form of teaching where students are separated from teachers, and ICT equipment is used to connect 
students, teachers, and the educational material. Similarly, Lionarakis (2005) has attached a deeply educational dimension to distance teaching, suggesting that "distance teaching activates students and teaches them how to learn on their own and operate with greater autonomy towards a more investigative process of self-learning and self-knowledge" that explicitly puts forward the issue of a student' self-regulation. Educational institutions have started to use various systems and distance teaching tools with certain countries attempting to implement a vision of urgent change on a national level.

In contrast, others have adopted specific solutions to maintain their education systems on an institutional and individual level, even though the results of any practice cannot be predicted yet (Agostinelli, 2019). However, one can postulate that schools or institutions with experienced educational personnel in the management of distance teaching systems and those who invest in the innovation of their technological resources will come out ahead as the educator's role will keep changing in the educational field after COVID-19 (Korkmaz \& Toraman, 2020). In the age of COVID, there are many problems educators deal with, such as access to appropriate applications, the use of digital tools, and the organization of digital educational activities (Depoux et al., 2020). One can state that educators' problems vary depending on children's age group and each educator's specific field. Today, in the 21 st century, as the current pandemic takes place, it is necessary that the learning process be enhanced using digital technologies and digital tools. In this context, educators assume significant responsibility in developing children's educational content and in their capacity to make them master new knowledge (Gözüm \& Demir, 2021).

\section{Distance teaching and preschool age in a digital era}

In a globalized teaching era, governmental organizations and educational institutions increasingly promote e-learning resulting in the transition from traditional classrooms to distance teaching (Aldhafeeri \& Khan, 2016). However, O’Doherty et al. (2018) have expressed concerns over the quality of online learning and the problems of distance education such as social isolation, lack of interaction and participation, delayed or unstable feedback (Khurana, 2016). According to the data gathered by UNESCO, in June 2020, over $75 \%$ of students worldwide were using distance learning and forcing both students and teachers into such a transition, organizing it as quickly as possible while ensuring the quality of the educational services resulted in divided opinions over distance education. With children of preschool age, learning at home means that parental support is required. Such a sudden shift in distance education and the emerging challenges cause concern. Without appropriate parental support, such changes may increase parents' likelihood of experiencing parental stress and parental exhaustion, which in turn can severely affect children (Griffith, 2020). However, parental opinions regarding the distance teaching experience to children of preschool and early primary school age, the emerging difficulties, the much-needed support, and the use of screen media at home by children have not been examined.

Educational technology applications have fostered math, science, literacy, and the learning of ideas through smart mobile devices and tablets. Nevertheless, it is a matter of discussion if all the educational technology applications developed for children of preschool age possess educational value. Papadakis \& Kalogiannakis (2020) examined the research regarding the educational value of digital applications from 2011 to 2019. The results suggested that most mobile phone applications with educational content targeting preschool-age children are noneducational and designed to entertain them. Furthermore, it has been suggested that parents and professional educators who assume the responsibility of children's development in early childhood have difficulty choosing digital applications with educational content (Hirsh-Pasek et al., 2015; Papadakis \& Kalogiannakis, 2017). However, the integration of technology in children's education by considering their age, level of development, individual interests and desires, and the social and cultural environment in which they belong is considered one of the significant realities of the contemporary world. In addition, it has become mandatory for children to meet technology after the pandemic Covid-19. Parents, teachers, and technology specialists have the responsibility to help them encounter the educational content of technology (Vidakis et al., 2019). The current study aims to examine through bibliography if preschool and early primary school children can be taught $\mathrm{CT}$ through distance teaching.

\section{Computational thinking and education}

CT is an essential competence for children in the 21 st century (Wing, 2016) and constitutes an essential issue in education (Lin et al., 2020). Over the past few years, an increased interest 
has been noted over CT education and its role in acquiring children's thinking skills and digital competencies (Angeli \& Giannakos, 2020; Chatzopoulos et al., 2021). Many countries have integrated CT into their curriculum (Webb et al., 2017) and have introduced Computer Science as a subject in primary education to train their students in designing computer programs (Heintz et al., 2016; Lindberg et al., 2019). Over the last few years, many claimed that CT could be acquired and developed by teaching programming to children. Furthermore, it has been advocated that such teaching must start as soon as possible (Heintz et al., 2016; Papadakis et al., 2021).

Programming based on blocks becomes how students are introduced to programming and Computer Science. With the popularity of tools such as Scratch, Alice, and Code. Org's Hour of Code, many new programming environments and initiatives employ the method based on blocks. This tendency can be found in the increasing number of curricula of Computer Science that incorporate environments based on blocks as part of their material (Brown et al., 2016). Programming environments are operating based on the logic of drag-drop such as App Inventor, Scratch (García-Peñalvo et al., 2016), Alice and Blockly (Aivaloglou \& Hermans, 2016) support new students in the development of CT during the programming activities by allowing them to focalize more on the process of solving problems through the transposition and deposition of blocks while they are learning.

On a national level, efforts have been made to promote CT learning at younger ages. Apart from appropriate programming environments, many efforts have been made towards distance learning thanks to the help of new technologies and the Internet to transmit knowledge and good practices (Papadakis, 2021a). The creation of Code.org, a non-profit organization, is considered vital as it envisions extending access to Computer Science at schools to enable any student in any school to have the opportunity to learn Computer Science as part of their fundamental education. For this reason, Code. org created the annual movement Hour of Code, in which more than 15\% of students participated from over 180 countries (Code, 2020 ). "codeacademy.com" offers learning environments fostering the learning of programming and CT through activities (Angeli \& Giannakos, 2020). Google developed CS first, a free computer science syllabus based on Scratch's application designed for students aged 9-14 years whom anybody can teach. Students are taught cooperation and basic terms of Computer Science as they create their projects while educators break ground with easy-to-use lesson plans, activities, and educational material (Code with Google, 2020). In addition, Scratch provides the opportunity to educators to make an application for an educator's account. This makes it easier for educators to create accounts for their students and manage their "digital class," projects, and commentary (Scratch-Educators, 2020).

In Europe, with the support of the European Commission, the European Code Week was started in 2013 by volunteers. In 2015, 570.000 participants from 46 countries took part in it with 7.600 activities, while in 2019 , the respective numbers were 4.200 .000 participants with 72.000 activities from more than 80 countries. The significant participation, the increasing interest, and the need to teach programming result in extending the period of "celebration." In 2021, the European Code Week will take place between the 9th and the 24th of October (Europe Code Week, 2020), providing the opportunity for educators and students to present their projects and work.

In this context, two free open online courses (MOOC - Massive Online Open Courses) were created in the educational portal European Schoolnet Academy. MOOCs belong to a category of asynchronous online learning; a student studies the learning material in his/her time, pace, and space, trying to follow the recommended timetable. The courses took place in 2019 (EU Code Week - Ice-breaker MOOC and EU Code Week - Deep Dive MOOC), and thanks to the great demand, they retook place in 2020. The two courses aimed to understand the significance of incorporating coding and CT in the classroom (European Schoolnet Academy, 2020). (see Figure 1)

After seeing the increased interest in the learning of programming and CT, attempts were made to train educators and students in Greece (Tzimopoulos et al., 2021a; Tzimopoulos et al., 2021b). The Educational Content, Methodology, and Technology Laboratory (ECMTL) of the Hellenic Open University (HOU) organized an educational workshop concerning Scratch Coding to learn basic coding terms in a Scratch environment. The workshop was organized using a mixed learning method, through distance learning, 30 hours for adults/educators and 6 hours for students (Scratch for teachers, 2020). Furthermore, to train educators in new technologies, programming through Scratch, and educational robotics, asynchronous workshops are organized in Greece by the National Support Service eTwinning in cooperation with training organizations (etwinning.gr, 2020). During the pandemic, in the educational field in Greece, two platforms for asynchronous learning were used (e-class and e-me). The latest upgrade of e-me in the 2.4 edition made it possible to attach Scratch files immediately (Digital Educational Platform e-me, 
2020). (see Figure 2)

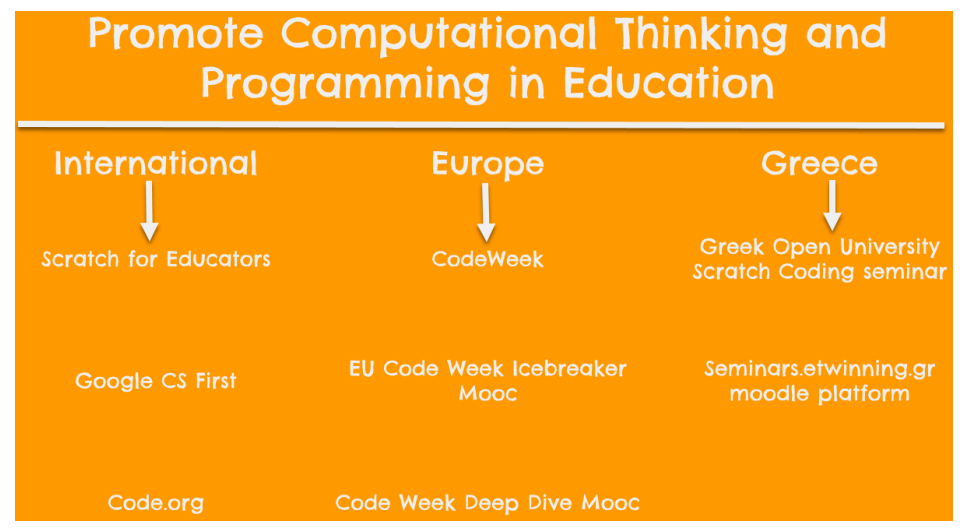

Figure 1 International initiatives to promote $\mathrm{CT}$ and programming in education

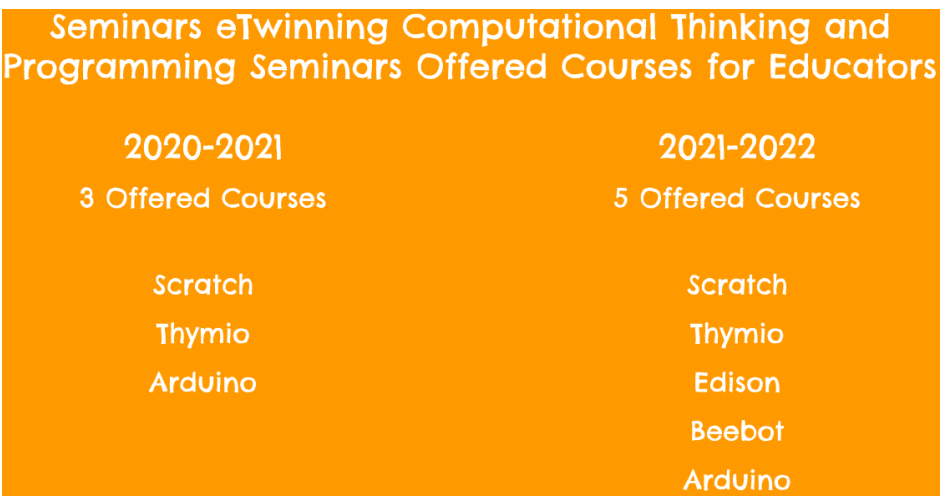

Figure 2 eTwinning seminars to promote CT and coding skills to educators

\section{Computational thinking and education in preschool age}

The universal tendency towards learning CT in education unveils the importance of programming lessons for children of preschool age (Lindberg et al., 2019). Since students of preschool age can practice their cognitive skills to solve basic computational logic, as a demographic, it has triggered significant interest in studying learning intentions and behaviors (Lin et al., 2020). The national study has pointed out that programming to young children plays a decisive factor in developing cognitive functions (Papadakis et al., 2016).

Little research has been conducted on students of preschool and early primary school age concerning CT (Poulakis \& Politis, 2019), and those that have been conducted have not managed to examine the results of teaching CT to children of kindergarten (Lin et al., 2020). In one of these studies, in 2020, Angeli and Valanides (Angeli \& Valanides, 2020) examined the consequences of CT through Bee-Bot learning in fifty children aged 5 and 6 . The study results illustrated statistically significant benefits between the initial and the final evaluation of children's CT skills. Through their research using kit-robotics to children aged 3-5, Bers et al. (2019) drew the same conclusions. They also pointed out that educators effectively incorporated coding activities and CT in their syllabus. A different study aimed to examine teaching practices' effect on children of preschool age to learn computational logic and coding terms to enhance their problem-solving and computational thinking skills. The results showed that using the developed system TUI based on play could increase the learning behaviors of children of preschool age and enhance their learning interests and computational thinking skills (Lin et al., 2020).

The advocate mentioned above that children of this age group can be taught $\mathrm{CT}$ if done correctly and with the appropriate means (Papadakis, 2021b). Nowadays, there are plenty of available programming environments suitable for educating children of preschool age. One of them that is free and popular is ScratchJr (Papadakis et al., 2016) that has been designed to be developmentally proper for students aged 5 to 7 in a similar manner to LightbotJr, which has 
a small purchase cost. The previously mentioned programming environments belong to the category of mobile programming environments. In addition, young students can use Web-based programming environments in programming and the development of CT such as Kodable and the section for children who do not know how to read via the use of special applications such as Code.com (Zaranis et al., 2019). (see Figure 3)

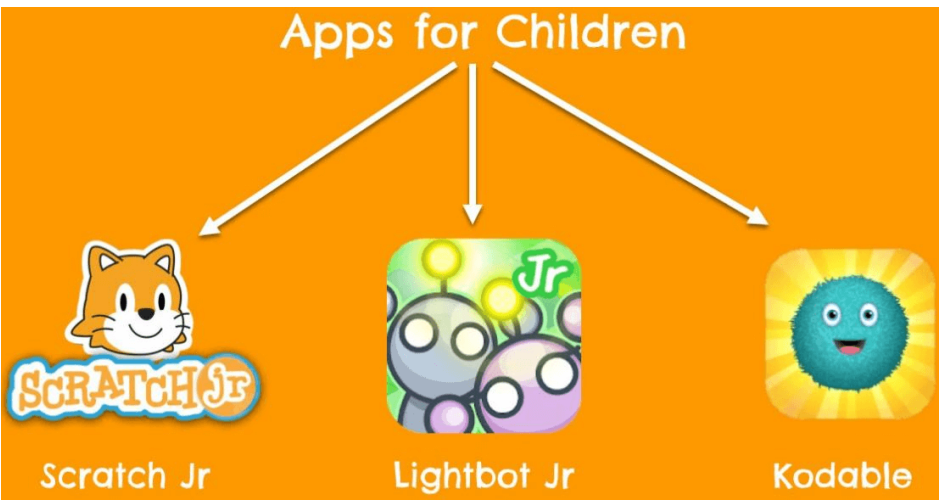

Figure 3 Apps for young age children to promote CT and coding skills

\section{Conclusion}

The current literature review shows how computational thinking has slowly been introduced in the school classroom. Many educators and parents identify the possible benefits that stem from the use of technology by children of younger ages; however, they do not have the appropriate pedagogical knowledge at their disposal to make proper use of it. Whether it is used in a formal or informal learning environment, technology should be used in ways that promote learning and children's healthy development (Lee, 2016). Nevertheless, educators and parents need to spend many hours searching for appropriate applications that support their students' or children's learning experiences (Papadakis \& Kalogiannakis, 2019). CT and students training in it will preoccupy us for the following years. It is an essential ability acquired from a very young age. The cooperation between teachers of preschool age and teachers of Information Technology could provide new dimensions and numerous benefits to the learning process.

Distance learning programs could be conducive to training educators to respond more effectively to the teaching of CT. Various organizations' training material exists, whether abroad or in Greece, although not providing sufficient educational material to cover teachers' and students' educational needs. It needs to be designed appropriately for distance learning purposes, and educators' training sessions should be based on it. At the same time, specific educational organizations specializing in teaching $\mathrm{CT}$ and programming to young children should be taken care of by the guidelines of appropriate educational material. With the appropriate cooperation and translation of the available activities from English to Greek, our young students can use that specific material to learn CT. As we find ourselves in the digital era, it becomes evident that attractive and entertaining processes such as those of CT pique children's interest while enabling them to get involved in active learning without much effort.

\section{References}

Agostinelli Jr, M. D. (2019). From distance education to online education: a review of the literature. Graduate Student Theses, Dissertations, \& Professional Papers, 11335. https://scholarworks.umt.edu/etd/11335

Aivaloglou, E., \& Hermans, F. (2016). How Kids Code and How We Know: An Exploratory Study on the Scratch Repository. Proceedings of the 2016 ACM Conference on International Computing Education Research, 53-61. https://doi.org/10.1145/2960310.2960325

Aldhafeeri, F. M., \& Khan, B. H. (2016). Teachers' and students' views on e-learning readiness in Kuwait's secondary public schools. Journal of Educational Technology Systems, 45(2), 202-235. https://doi.org/10.1177/0047239516646747

Alea, L. A., Fabrea, M. F., Roldan, R. D. A., \& Farooqi, A. Z. (2020). Teachers' Covid-19 awareness, distance learning education experiences and perceptions towards institutional readiness and challenges. International Journal of Learning, Teaching and Educational Research, 19(6), 127-144. https://doi.org/10.26803/ijlter.19.6.8 
Ampartzaki, M., Kalogiannakis, M., \& Papadakis, S. (2021). Deepening Our Knowledge about Sustainability Education in the Early Years: Lessons from a Water Project. Education Sciences, 11(6), 251. https://doi.org/10.3390/educsci11060251

Angeli, C., \& Giannakos, M. (2020). Computational thinking education: Issues and challenges. Computers in Human Behavior, 105, 106185. https://doi.org/10.1016/j.chb.2019.106185

Angeli, C., \& Valanides, N. (2020). Developing young children's computational thinking with educational robotics: An interaction effect between gender and scaffolding strategy. Computers in Human Behavior, $105,105954$. https://doi.org/10.1016/j.chb.2019.03.018

Bers, M. U., González-González, C., \& Armas-Torres, M. B. (2019). Coding as a playground: Promoting positive learning experiences in childhood classrooms. Computers \& Education, 138, 130-145. https://doi.org/10.1016/j.compedu.2019.04.013

Brown, N. C. C., Mönig, J., Bau, A., \& Weintrop, D. (2016). Panel: Future Directions of Block-based Programming. Proceedings of the 47th ACM Technical Symposium on Computing Science Education, 315-316. https://doi.org/10.1145/2839509.2844661

Chatzopoulos, A., Kalogiannakis, M., Papadakis, S., Papoutsidakis, M., Elza, D., \& Psycharis, S. (2021). DuBot: An Open-Source, Low-Cost Robot for STEM and Educational Robotics. In Handbook of Research on Using Educational Robotics to Facilitate Student Learning (pp. 441-465). IGI Global. https://doi.org/10.4018/978-1-7998-6717-3.ch018

Code with Google. (2020). Google for Education. Retrieved 2 December, 2021. https://edu.google.com/code-with-google

Code.org. (2020). Retrieved December 17, 2021. https://code.org/about

Depoux, A., Martin, S., Karafillakis, E., Preet, R., Wilder-Smith, A., \& Larson, H. (2020). The pandemic of social media panic travels faster than the COVID-19 outbreak. https://doi.org/10.1093/jtm/taaa031

Europe Code Week. (2020). Retrieved December 27, 2020. https://codeweek.eu

European Schoolnet Academy. (2020). Retrieved 2 December 2021. https://www.europeanschoolnetacademy.eu/dashboard

Fessakis, G., Lappas, D. \& Mavroudi, E. (2015). 'Could computer games-based problem solving positively affect the development of creativity in young children? A mixed method case study'. In K.L. Heider \& M. Renck Jalongo (Eds.): Young Children and Families in the Information Age, Educating the Young Child, 207-225. Dordrecht: Springer. https://doi.org/10.1007/978-94-017-9184-7_12

García-Peñalvo, F. J., Rees, A. M., Hughes, J., Jormanainen, I., Toivonen, T., \& Vermeersch, J. (2016). A survey of resources for introducing coding into schools. Proceedings of the Fourth International Conference on Technological Ecosystems for Enhancing Multiculturality, 19-26. https://doi.org/10.1145/3012430.3012491

Gözüm, A., \& Demir, O. (2021). Prospective preschool teachers' technological pedagogical content knowledge self-confidence for science education in the age of COVID-19: A Structural Equational Modelling: Prospective preschool teachers' technological pedagogical content knowledge. Retrieved December 05, 2021. http://ijci.wcci-international.org/index.php/IJCI/article/view/599

Griffith, A. K. (2020). Parental burnout and child maltreatment during the COVID-19 pandemic. Journal of family violence, $1-7$. https://doi.org/10.1007/s10896-020-00172-2

Guernsey, L., \& Levine, M. H. (2016). Nurturing Young Readers: How Digital Media Can Promote Literacy Instead of Undermining It. American Educator, 40(3), 23.

Heintz, F., Mannila, L., \& Farnqvist, T. (2016). A review of models for introducing computational thinking, computer science and computing in K-12 education. 2016 IEEE Frontiers in Education Conference (FIE), 1-9. https://doi.org/10.1109/FIE.2016.7757410

Hirsh-Pasek, K., Adamson, L. B., Bakeman, R., Owen, M. T., Golinkoff, R. M., Pace, A., ... \& Suma, K. (2015). The contribution of early communication quality to low-income children's language success. Psychological science, 26(7), 1071-1083. https://doi.org/10.1177/0956797615581493

Kalogiannakis, M., Ampartzaki, M., Papadakis, S., \& Skaraki, E. (2018). Teaching natural science concepts to young children with mobile devices and hands-on activities. A case study. International Journal of Teaching and Case Studies, 9(2), 171-183. https://doi.org/10.1504/IJTCS.2018.090965

Khurana, M. (2016). Leveraging ICT for improving public service delivery.

Korkmaz, G., \& Toraman, Ç. (2020). Are we ready for the post-COVID-19 educational practice? An investigation into what educators think as to online learning. International Journal of Technology in Education and Science (IJTES), 4(4), 293-309. https://doi.org/10.46328/ijtes.v4i4.110

Lin, S. Y., Chien, S. Y., Hsiao, C. L., Hsia, C. H., \& Chao, K. M. (2020). Enhancing Computational Thinking Capability of Preschool Children by Game-based Smart Toys. Electronic Commerce Research and Applications, 44, 101011. https://doi.org/10.1016/j.elerap.2020.101011 
Lindberg, R. S. N., Laine, T. H., \& Haaranen, L. (2019). Gamifying programming education in K-12: A review of programming curricula in seven countries and programming games. British Journal of Educational Technology, 50(4), 1979-1995. https://doi.org/10.1111/bjet.12685

O’Doherty, D., Dromey, M., Lougheed, J., Hannigan, A., Last, J., \& McGrath, D. (2018). Barriers and solutions to online learning in medical education-an integrative review. BMC medical education, $18(1), 130$. https://doi.org/10.1186/s12909-018-1240-0

Papadakis, S. (2021a). The impact of coding apps on young children Computational Thinking and coding skills. A literature review. In Frontiers in Education, 6, 183). https://doi.org/10.3389/feduc.2021.657895

Papadakis, S. (2021b). Advances in Mobile Learning Educational Research (AMLER): Mobile learning as an educational reform. Advances in Mobile Learning Educational Research, 1(1), 1-4. https://doi.org/10.25082/AMLER.2021.01.001

Papadakis, S., \& Kalogiannakis, M. (2017). Evaluation of Greek Android mobile applications for preschoolers. Preschool and Primary Education, 5(2), 65-100. https://doi.org/10.12681/ppej.11208

Papadakis, S., \& Kalogiannakis, M. (2020). A research synthesis of the real value of self-proclaimed mobile educational applications for young children. Mobile learning applications in early childhood education, 1-19. https://doi.org/10.4018/978-1-7998-1486-3.ch001

Papadakis, S., Alexandraki, F. \& Zaranis, N. Mobile device use among preschool-aged children in Greece. Educ Inf Technol (2021). https://doi.org/10.1007/s10639-021-10718-6

Papadakis, S., Kalogiannakis, M., \& Zaranis, N. (2016). Developing fundamental programming concepts and computational thinking with ScratchJr in preschool education: A case study. International Journal of Mobile Learning and Organisation, 10(3), 187. https://doi.org/10.1504/IJMLO.2016.077867

Papadakis, St., \& Kalogiannakis, M. (2019). Evaluating a Course for Teaching Advanced Programming Concepts with Scratch to Preservice Kindergarten Teachers: A Case Study in Greece. In D. FarlandSmith (Eds.) Early Childhood Education (pp. 1-19)/ UK-London: IntechOpen Limited. https://doi.org/10.5772/intechopen.81714

Pinto, J. D., Quintana, C., \& Quintana, R. M. (2020). Exemplifying Computational Thinking Scenarios in the Age of COVID-19: Examining the Pandemic's Effects in a Project-Based MOOC. Computing in Science \& Engineering, 22(6), 97-102. https://doi.org/10.1109/MCSE.2020.3024012

Scratch for teachers - EEYEM, 2020. https://eeyem.eap.gr/scratch-for-teachers

Scratch-Educators, 2020. https://scratch.mit.edu

Skaraki, E. (2021). Reinforcing preschoolers' phonemic awareness through the use of tablets. Advances in Mobile Learning Educational Research, 1(1), 28-36. https://doi.org/10.25082/AMLER.2021.01.004

Tzimopoulos, N., Provelengios, P., \& Iosifisou, M. (2021a). Emergency remote teaching in Greece during the first period of the 2020 Covid-19 pandemic. Advances in Mobile Learning Educational Research, $1(1), 19-27$. https://doi.org/10.25082/AMLER.2021.01.003

Tzimopoulos, N., Provelengios, P., \& Iosifisou, M. (2021b). Implementation and evaluation of a remote seminar on the pedagogical use of educational robotics. Advances in Mobile Learning Educational Research, 1(2), 48-57. https://doi.org/10.25082/AMLER.2021.02.001

Vaiopoulou, J., Papadakis, S., Sifaki, E., Stamovlasis, D., \& Kalogiannakis, M. (2021). Parents' Perceptions of Educational Apps Use for Kindergarten Children: Development and Validation of a New Instrument (PEAU-p) and Exploration of Parents' Profiles. Behavioral Sciences, 11(6), 82. https://doi.org/10.3390/bs11060082

Vidakis, N., Barianos, A. K., Trampas, A. M., Papadakis, S., Kalogiannakis, M., \& Vassilakis, K. (2019). in-Game Raw Data Collection and Visualization in the Context of the "ThimelEdu" Educational Game. In International Conference on Computer Supported Education, 629-646. Springer, Cham. https://doi.org/10.1007/978-3-030-58459-7_30

Webb, M., Davis, N., Bell, T., Katz, Y., Reynolds, N., Chambers, D. P., \& Sysło, M. M. (2017). Computer science in K-12 school curricula of the 2lst century: Why, what and when? Education and Information Technologies, 22(2), 445-468. https://doi.org/10.1007/s10639-016-9493-x

Wing, J. (2011). Research notebook: Computational thinking-What and why. The link magazine, 6

Wing, J. M. (2006). Computational thinking. Communications of the ACM, 49(3), 33-35. https://doi.org/10.1145/1118178.1118215

Wing, J. M. (2016). Computational thinking, 10 years later. https://www.microsoft.com/en-us/research/blog/computational-thinking-10-years-later 